\title{
Understanding the role of visuals in commercial website interaction on smartphone display
}

\author{
Achmad Syarief, ${ }^{1 *}$ Nedina Sari, ${ }^{2}$ Amanda Amelia ${ }^{3}$ \\ ${ }^{1,2,3}$ Program Studi Desain Produk, FSRD Institut Teknologi Bandung, Bandung Indonesia
}

\begin{abstract}
Flexible and ease of internet access through mobile device in Indonesia has changed the way users interact with commercial websites, especially online ticketing service website. Yet, no study on how the presented website visuals on smartphone display perceived and experienced by users is found. This paper exposes users' interactive experience on smartphone display, showcasing 3 (three) popular online ticketing service providers in Indonesia, traveloka dot com, pegi-pegi dot com, and tiket dot com. 60 individuals were purposively sampled and each was asked to access all chosen websites using provided smartphone. 2 (two) pages follow-up questionnaire was presented to each respondent: first page is for identifying users' perception 5 (five) items likert-scale responses and second page is for identifying users' experiences using Schrepp, Hinderks \& Thomaschewski's UXQ (User Experience Questionnaire). Results show that when interacting with online ticketing service websites on smartphone, sites that look simple and easy to interact with may provide sense of savvyness, comfortability, and security. This indicates that presented website visuals on smartphone display affect users' experience when using online services. Although further studies are needed, this results offer valuable insights to the discussions of human interactive experience in using online platform.
\end{abstract}

Key words: users' experiences, online services, site's appearance, smartphone display

\begin{abstract}
Abstrak
Kemudahan dan fleksibilitas akses internet melalui perangkat telepon seluler mengubah cara pengguna berinteraksi dalam dunia ecommerce di Indonesia. Salah satu dari sekian banyak kategori website komersial yang bertumbuh cepat adalah website layanan tiket secara daring. Namun tidak ditemui adanya studi yang mengidentifikasi relasi tampilan visual website pada layar smartphone terhadap persepsi dan pengalaman pengguna saat mengadopsi layanan website komersial. Dalam studi ini dikaji respon pengguna terhadap tampilan visual website komersial pada layar smartphone menggunakan 3 (tiga) penyedia layanan tiket secara daring yang popular di kalangan pengguna Indonesia, traveloka dot com, pegi-pegi dot com, dan tiket dot com. 60 orang responden dilibatkan untuk mengakses ketiga penyedia layanan tiket daring dan merespon pertanyaan kuesioner dalam 2 (dua) tahap yaitu respon perseptual menggunakan 5-item skala likert dan respon pengalaman menggunakan kuesioner UXQ Schrepp, dkk. Hasil menunjukkan bahwa saat berinteraksi dengan layanan website pada layar smartphone, tampilan website yang terlihat lebih simple dan mudah dipahami memunculkan persepsi kehandalan, kenyamanan, dan keamanan pada website. Hal tersebut mengindikasikan bahwa visualisasi website pada layar smartphone mempengaruhi pengalaman pengguna atas layanan yang diberikan. Walaupun studi lanjutan masih diperlukan, hasil analisis dapat menjadi landasan pengetahuan untuk mengkaji relasi pengalaman interaktif manusia saat mengadopsi layanan komersial secara daring.
\end{abstract}

Kata kunci: pengalaman pengguna, layanan daring, tampilan situs, display ponsel

\section{Introduction}

A more dependable satellite network and internet technology coupled with positive economic growth in the last 3 (three) years generate the booming of online commerce and/or service in Indonesia. Study by statista dot com (2017) showed that "...with over 104 million internet users, Indonesia is one of the biggest online markets worldwide...Mobile internet usage is undergoing double-digit growth rates and currently stands at close to 30 percent among population." Survey by statista dot com (2017) predicts that in the year of 2023 there will be over 100 million mobile phone internet users in Indonesia.

Interestingly, due to the flexibility and easeness of usage through mobile device, the way Indonesian consumers interact with commerce has changed. Using website as platform, product and/or services are

\footnotetext{
* Corresponding author Tel : +62-813-1202-8424 ; e-mail : asyarief.phd@gmail.com
} 
interchanged at ease, contact between seller and buyer comes in a more fluid manner. One of many categorical website services that grows rapidly is travel websites, especially online ticketing service website. This was evidential as study by statista shows that in 2019, revenue in travel and tourism market of Indonesia reach the amount of US\$6,992 millions, with some some $57 \%$ percent use to book flight tickets through online. Yet other than a wellinvestigated study results by statista on Indonesia online market (see: Statista Global Consumer Survey, 2017), there is no study on how the presented travel website visuals on smartphone display perceived and experienced by users is found. Based on this premise, the paper exposes users' responses on website visuals on smartphone display, showcasing 3 (three) popular online ticketing service providers in Indonesia, traveloka dot com, pegi-pegi dot com, and tiket dot com.

Many websites have not necessarily been designed with the users in mind. In many cases, commercial websites were designed and engineered to perform merely a set of interactions, using menus and links with icons, symbols, and/or graphics, especially when recent software development can help novice users to build a website in an easy and available way. However, while the sites may effectively work from program-performance -related perspective, it is often at the expense of how the sites are viewed and actually experienced by the real users. However, recent advances of the internet and multimedia contents let web users extend their demands from web pages, not only from performance-related perspective but also from having appropriate visual appeal. Research by Kim-Moon [1998] mentioned that when used for commercial purpose, the necessity to consider the aesthetics aspect of web pages is increased. This is because aesthetics impression was found to influence both users' memories and their decisions process when they purchase the product [Kim-Moon, 1998; Lee, 1998]. In addition, study by Schenkman and Jonsson's (2000) suggested that beauty is a primary predictor of overall impression and preferences of websites. This new wave of researches on visual aesthetics suggest that aesthetics is a strong determinant of pleasure experienced by the users during the interaction. If once the value of computing technology and the World Wide Web were associated mostly by how it performs and be used to assist users, other necessity "requirement" such as how it effectively appeal to users and consciously persuade their behaviors have now emerged. Issues of visual appeal, beauty, and/or aesthetics become an integral part of the web world and no longer plays negligible role in the human-computer interaction research. Although focused on desktop platform, previous research on website visuals (Syarief-Hibino, 2005; Syarief-Hibino, 2007, and Nasrul et.al, 2012) acknowledged that visually appealing website has significant effect in attracting users' attention and trust. Consequently, websites that are easily to interact with and provides a higher quality of visual comfort may have higher possibility to persuade commercial transaction. Accordingly, the study look upon discussions of human interactive experiences and its relation to website visuals on mobile device with travel websites as cases.

\section{Method}

The objective of this study is to identify users' perception and experiences when interacting with travel website visuals presented on mobile devices. For this purpose, Schrepp, Hinderks, and Thomaschewski's scale (2014) of user's experience was applied. The UX's scale is deemed suitable to compare different commercial sites that have similar function and/or purpose. It is based on 6 (six) scales of measurement: (1) Attractiveness, the overall impression of product; (2) Perspicuity, the easeness and familiarity of using product; (3) Efficiency, the speed of concluding the task; (4) Dependability, the ability to control, secure and predict action; (5) Stimulation, the excitement, motivating, and fun of using product; and (6) Novelty, the interest toward product.

These scales are based on semantic differential method, with which users' responses are measured using series of bi-polar adjective words (Schrepp et al, 2008). Each scale relates to certain dimesion and/or quality. Attractiveness is a pure valence dimension. Perspicuity, Efficiency and Dependability are pragmatic quality aspects (goal-directed), while Stimulation and Novelty are hedonic quality aspects (not goal-directed). The Attractiveness scale has 6 (six) items, while Perspicuity, Efficiency, Dependability, Stimulation and Novelty scales have 4 (four) items (see Figure 1).

As the study focuses on travel websites, 3 (three) online travel related service providers in Indonesia were selected. They are: pegi pegi dot com (identified as Site 1), traveloka dot com (identified as Site 2), and tiket dot com (identified as Site 3). Those sites are regarded as the top 3 (three) of Indonesian mobile travel and tourism websites according to similar-web dot com (2019). 


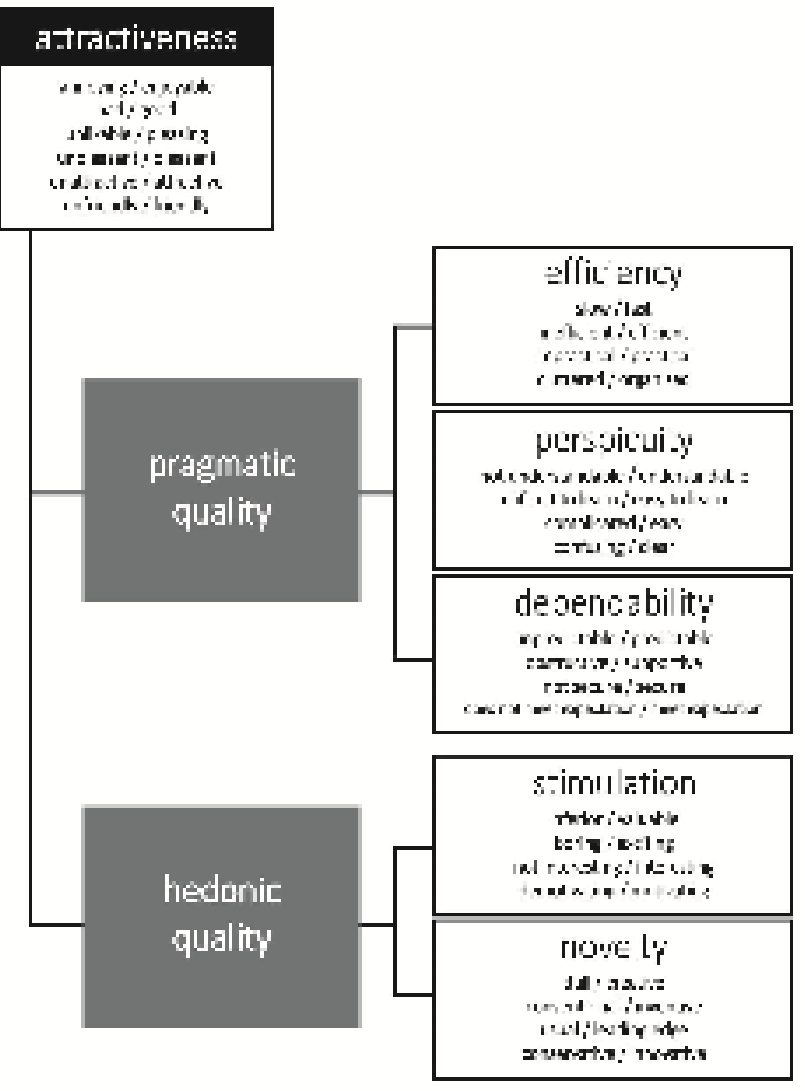

Fig 1. Scales of users' experience measurement (adapted from Schrepp et al, 2014)

Due to huge varieties of mobile devices, a standard 6.0 inch Android-based " $\mathrm{X}$ " smartphone was used in the experiment. Speed of internet connection was monitored, to assure a comparable internet access quality when browsing the intended sites.

Sixty individuals were purposively involved as participants. All participants had normal or corrected to normal vision, and none have any type of color deficiency prior to the study. All participants have no prior knowledge nor experiences in accessing online travel websites. Each participant was asked to access all chosen websites using provided smartphone with 60 seconds blank interval in between sites. A followup 2 (two) pages questionnaire was presented to each respondent: first page and second page. First page is for identifying users' perception using 5 (five) items likert-scale responses (strongly agree $=5$ to strongly disagree $=1$ ) on 5 (five) perceptual questions:

a. Interaction-related quality: (1) Savvyness of using smartphone to access online travel sites. How savvy are you?; (2) Comfortability of using smartphone to access online travel sites. How comfortable are you?; (3) Security of using smartphone to access online travel sites. How secure are you?

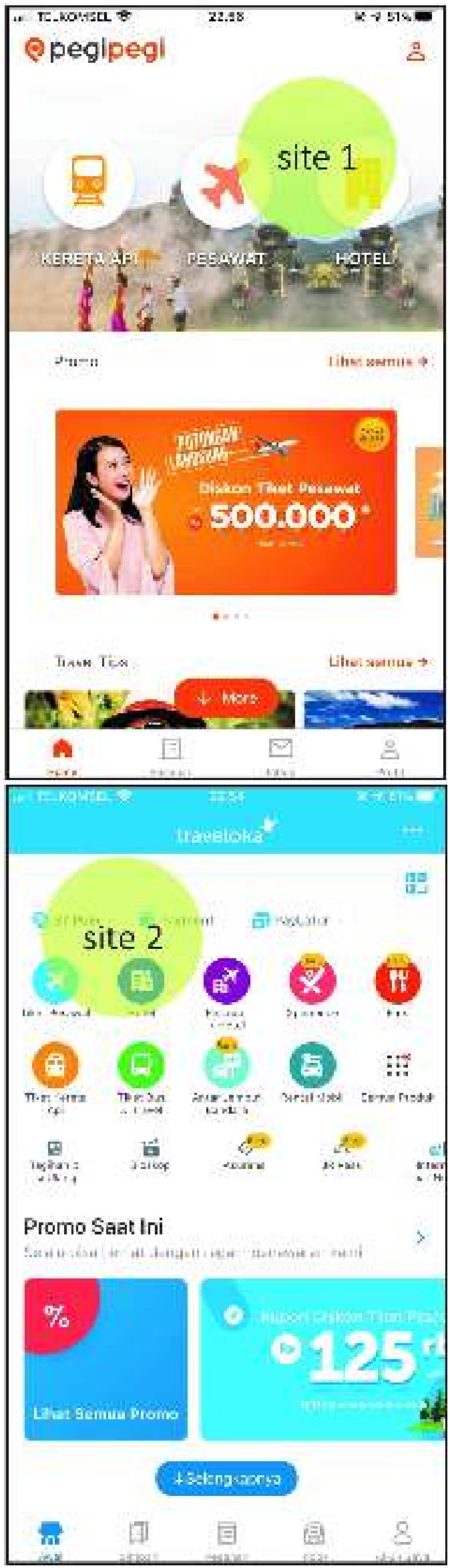




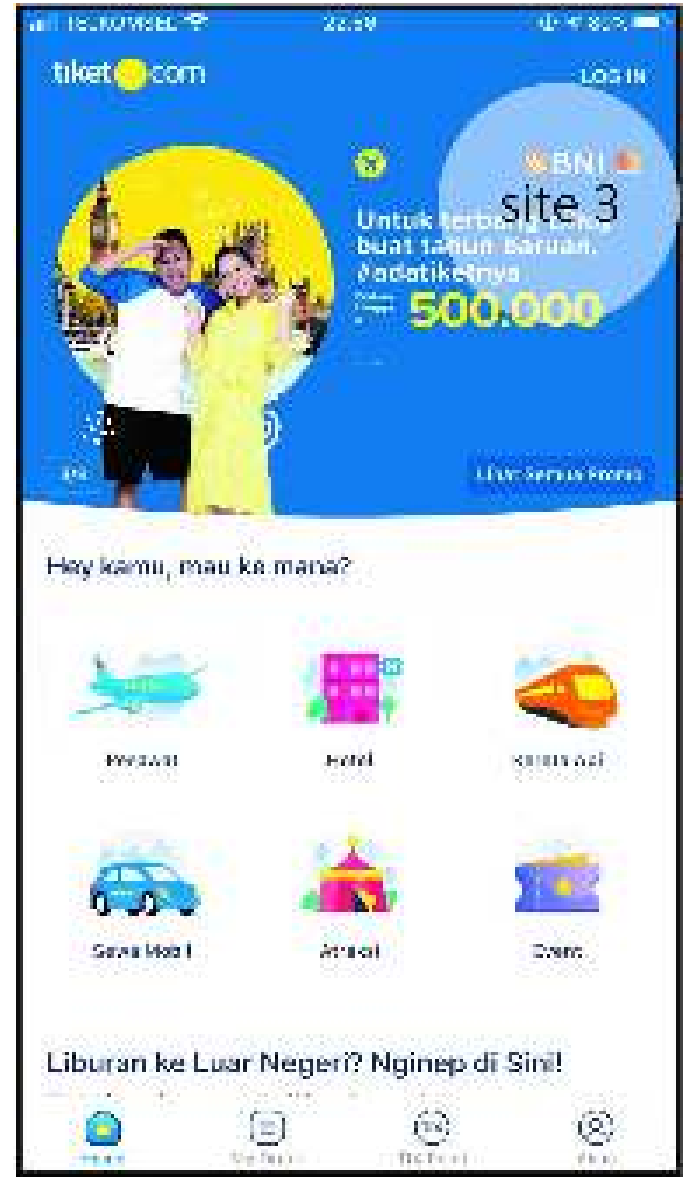

Fig 2. Object of research (Site 1, 2, and 3)

b. Design-related quality: (1) Simple-ness of appearance when interacting with travel sites' visuals. How simple is it?; (2) Ease of use when interacting with travel sites' navigation. How easy is it to navigate?

The second page is for identifying users' experiences using Schrepp, Hinderks \& Thomaschewski's UXQ (User Experience Questionnaire) as explained in figure 1.

\section{Results and Discussions}

Results show that female users $(n=36)$ tend to be more savvy (avg score $=4.11$ on scale of 5), have more comfort (avg score $=3.611$ ), and felt more secure (avg score $=3.611$ ) on accessing online travel sites using smartphone than male users $(n=24)$. Male users tend to be less savvy (4.00), have less comfort (3.33), and felt less secure (3.29). Interestingly, those results are comparable to design-related quality as female users are also have tendency to assess higher scores on design-related quality than male users (see table 1).

Although results are based on small numbers of respondents $(n=60)$, nevertheless its findings may suggest some intriguing points: (a) Female users tend to have ease and more immerse in using mobile device to access information and/or service on web than male users; and (b) perception on elements of interaction-related quality relate to design-related quality. Thus, a site that looks simple and easy to interact with may provide sense of savvyness, comfortability, and security for users. This indicates that presented website visuals on smartphone display may affect users' interests to approach provided services.

Further, order of ranking for all sample sites shows that male users tend to order them decisively. According to their scores of ra nk value, site 2 (traveloka) is ranked number 1 (avg score $=2.37)$, site 3 (tiket dot com) is ranked number 2 (avg score $=$
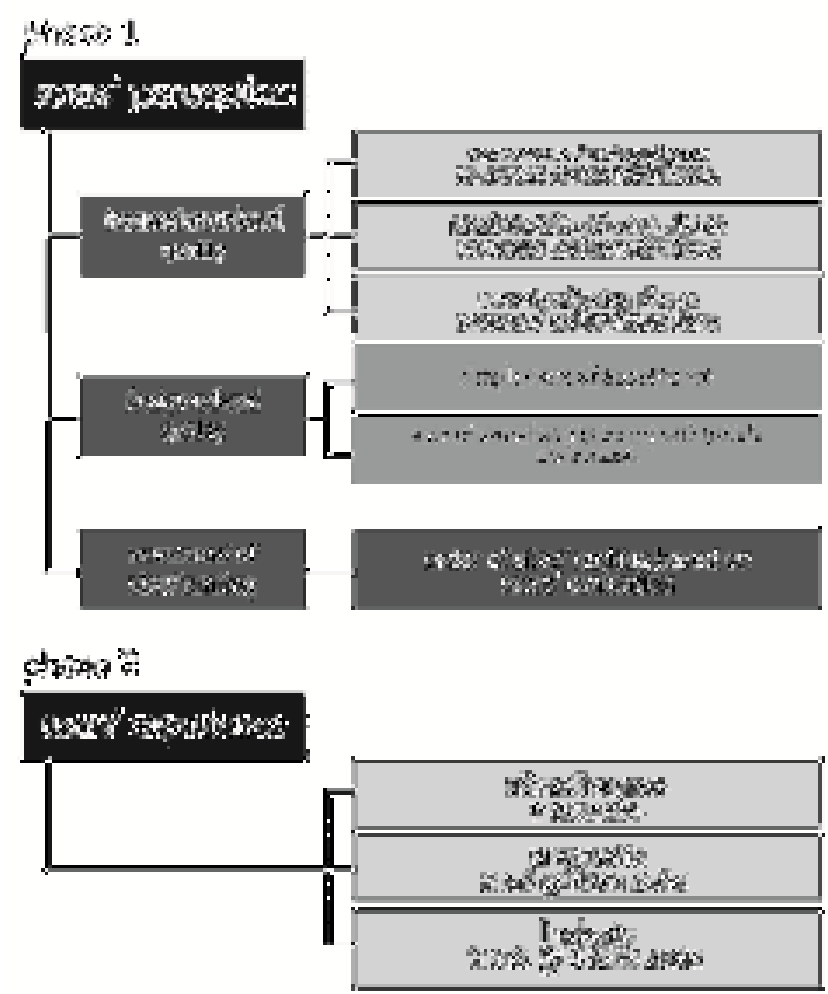

Fig 3. Procedures of Research

Table 1. Perceptual scores on design-related quality

\begin{tabular}{c|c|c|}
\hline & $\begin{array}{c}\text { Female } \\
(\mathrm{n}=36)\end{array}$ & $\begin{array}{c}\text { Male } \\
(\mathrm{n}=24)\end{array}$ \\
\hline Perceived Simplicity & 3.92 & 3.41 \\
Perceived Ease of Use & 3.58 & 3.50 \\
\hline
\end{tabular}

Note: base on 5 (five) interval likert-scales 
1.917), and site 1 (pegi-pegi dot com) is ranked number 3 (avg score $=1.708$ ). On the other hand, female users tend to vague in ranking of those sites although number 1 rank is similar to those of male users. Results show that female users rank site 2 (traveloka) as number 1 (avg score $=2.50)$, site 3 (tiket dot com) and site 1 (pegi-pegi dot com) are on par rankings (both scores $=1.75$ ). This suggests that male users tend to be decisive in determining quality of sites's visual appearance, while female users tend to be indecisive and may easily sway by the sites' visual appearance; although further study is needed to determine this suggestion.

\section{Users' Experiences when Interacting with Website Visuals}

Composite results of users' experience study are presented in tabel 2. The findings suggest that site 2 (traveloka dot com) has highest score on all scales: Attractiveness (1.358), Perspicuity (1.496), Efficiency (1.488), Dependability (1.125), Stimulation (1.079) and Novelty (0.536) compare to site 1 (pegi-pegi dot com) and site 3 (tiket dot com). In addition, site 1 has negative score on scale of novelty $(-0.267)$, which means that users posses negative experience in relating to scale of novelty. It indicates that when interacting with site 1 , users perceived the site to be dull, conventional, too common, and conservative compare to other sites.

By exploring dimension of pragmatic and hedonic quality (Schreep et al, 2014), results show that site 2 has higher scores (pragmatic quality score/pqs $=1.36$, hedonic quality score/hqs $=0.81$ ) compare to site 1 $(\mathrm{pqs}=1.10, \mathrm{hqs}=0.08)$ and site $3(\mathrm{pqs}=1.00, \mathrm{hqs}=$ 0.45 ). Interestingly, site 1 has less score on hqs compare to site 3 . This indicates that a site mayworks and perform well but perceived to be boring, not interesting, dull, conventional, usual and conservative by users. Interestingly, a site that has higher hedonic

Table 2.1 Composite results of users/experience

\begin{tabular}{rcc|c|}
\hline & Site 1 & Site 2 & Site 3 \\
\hline Atrractiveness & 0.748 & $\mathbf{1 . 3 5 8}$ & 0.967 \\
Perspicuity & 1.125 & $\mathbf{1 . 4 9 6}$ & 1.079 \\
Efficiency & 1.208 & $\mathbf{1 . 4 8 8}$ & 1.021 \\
Dependability & 0.968 & $\mathbf{1 . 1 2 5}$ & 0.913 \\
Stimulation & 0.429 & $\mathbf{1 . 0 7 9}$ & 0.754 \\
Novelty & $\mathbf{- 0 . 2 6 7}$ & $\mathbf{0 . 5 3 6}$ & 0.149 \\
\hline
\end{tabular}

Table 2.2 Scores on pragmatic and hedonic quality

\begin{tabular}{r|c|c|c}
\hline & Site 1 & Site 2 & Site 3 \\
\hline Atrractiveness & 0.748 & $\mathbf{1 . 3 5 8}$ & 0.967 \\
Pragmatic Quality & 1.10 & $\mathbf{1 . 3 7}$ & 1.00 \\
Hedonic Quality & 0.08 & $\mathbf{0 . 8 1}$ & 0.45 \\
\hline
\end{tabular}

quality score tend to have higher attractiveness score as well. This may indicates that a site will be perceived to be attractive if it can stimulate positive experiences (valuable, exciting, interesting, motivating, creative, inventive, leading edge and meet users/expectation). Consequently, positive experience may affect the way users interact with a site in order to develop his/her willingness to approach offered service. This result is corroborated with previous similar research on the relation of website visuals and users' interest on desktop monitor ((Syarief-Hibino, 2005; Syarief-Hibino, 2007). Therefore, it can be suggested that the probability to gain commercial transaction increases when the viewed service websites present positive experiences and attract users' attention.

\section{Conclusions}

Composite results indicates that presented website visuals on smartphone display influence users' interest to adopt provided services and further their interactions. Therefore, it can be deduced that easeness of use and the perceived simplicity of websites' appearances may increase the probability to have commercial transaction. This result is corroborated with previous similar research on the relation of website visuals and users' interest on desktop monitor. Thus, it can be suggested that changes of medium of deliveries (whether its stationary display or mobile screen) do not necessarily have different effects on users. Although further studies are needed to expose phenomena of online commerce as experienced by users, nevertheless these results offer valuable insights to the discussions of human interactive experience in relation to visuals of object and their ndonesia ed context with commercial service.

\section{Acknowledgment}

The research is partially supported by 2019-2020 ITB Research Grant (P3MI Programme)

\section{References}

Kim, J, and Moon, J. (1998). Designing toward Aesthetics Usability in Customer Interface. Interacting with Computers, 10 (1), pp. 1-29.

Kim, J, and Moon, J. (1998). Philosophical Discussion on the Science of Emotion and Sensibility. Journal of Emotion and Sensibility, 1 (1), pp. 3-11.

Lee, K. (1998). Sensibility Ergonomics in Social and Industrial Environment. Journal of the Ergonomics Society of Korea, 17 (1), pp. 13-17 
Nasrul, M.A, Nor, Khalil Md., Masrom, M., and Syarief, A. (2012). Website Fit: An Overview. Proceedia Social and Behavioral Science 40 (2012), p 315-325. ScieVerse Science Direct

Schenkman, B., and Jonsson, F. (2000). Aesthetics and Preferences of Web Pages. Behavior and Information Technology, 19 (5), pp. 367-377.

Schrepp, M.; Hinderks, A. \& Thomaschewski, J. (2014). Applying the User Experience Questionnaire (UEQ) in Different Evaluation Scenarios. In: Marcus, A. (Ed.): Design, User Experience, and Usability. Theories, Methods, and Tools for Designing the User Experience. Lecture Notes in Computer Science, Volume 8517, pp. 383-392, Springer International Publishing.

SimilarWeb (2019). Top Sites Ranking for Travel and Tourism in Indonesia. Access: https://www.similarweb.com/top-websites/ ndonesia/category/travel-and-tourism (October, 2019).

Statista dot com. (2017). Number of Internet Users in Indonesia. Access: http://www.statista.com/ statistics/ 254456/ numberof-internet-users-in Indonesia/

Syarief, Achmad and Hibino, Haruo. (2005). Examining the effect of Web Design Convention on Site's Persuasive Qualities. Proceeding of the International Ergonomic Conference on Human Work and Working Environment (HWWE), IIT Guwahati INDIA (December, 2005)

Syarief, Achmad and Hibino, Haruo. (2007). Looking into the credibility of appearance: Exploring the role of color in interface aesthetics and how it affects our perception on system's credibility. ITB Journal of Visual Art and Design, Vol 1 No 1, ITB: Bandung, pp 1-9 